\title{
Storage of 'Palmer' mangoes in low-oxygen atmospheres
}

\author{
Gustavo Henrique De AlmeIDA TeIXEIRA ${ }^{1 *}$, José Fernando DURIGAN ${ }^{2}$
}

\author{
${ }^{1}$ Fac. Ciênc. Farm. Ribeirão \\ Preto, Univ. São Paulo, Dep. \\ Anál. Clín., Toxicol. Bromatol., \\ Av. do Café, s/n, Campus Univ. \\ USP, Ribeirão Preto, SP-Brasil, \\ CEP: 14.040-903, \\ gustavo@fcfrp.usp.br \\ 2 UNESP - Univ. Estadual \\ Paulista, Fac. Ciênc. Agrár. \\ Vet., Dep. Tecnol., Via de \\ acesso Prof. Paulo Donato \\ Castellane s/n, Jaboticabal, \\ SP-Brasil, CEP: 14.884-900
}

${ }^{*}$ Correspondence and reprints

Received 10 September 2010 Accepted 17 November 2010

Fruits, 2011, vol. 66, p. 279-289 (C) 2011 Cirad/EDP Sciences All rights reserved DOI: 10.1051/fruits/2011037 www.fruits-journal.org

RESUMEN ESPAÑOL, p. 289

\section{Storage of 'Palmer' mangoes in low-oxygen atmospheres.}

Abstract - Introduction. Mango conservation under traditional refrigeration systems is not totally efficient due to the susceptibility of this fruit to chilling injury, but controlled atmosphere (CA) in association with low temperature can improve its storability and maintain fruit quality during storage. Thus, the aim of our study was to determine the effect of CA with varied concentrations of oxygen during cold storage $\left(12.8{ }^{\circ} \mathrm{C}\right)$ of 'Palmer' mango fruit. Materials and methods. Mature green mango fruit were stored in atmospheres with (1\%, 5\%, 10\%, 15\% and $21 \%)$ oxygen at $(12.8 \pm 0.6){ }^{\circ} \mathrm{C}$ and $\left.\mathrm{RH} \sim 95 \%\right)$ for up to 28 days. A group of fruits without CA was stored in a cold room and served as tray-stored control. Fruit ripening was carried out in ambient conditions $\left.\left[(25.2 \pm 0.6){ }^{\circ} \mathrm{C},(92.8 \pm 2.4) \% \mathrm{RH}\right)\right]$ at intervals of $14 \mathrm{~d}$. Results and discussion. Fruits stored in low-oxygen concentrations $\left[(1 \%, 5 \%\right.$ and $\left.10 \%) \mathrm{O}_{2}\right]$ had significantly lower rates of $\mathrm{CO}_{2}$ production after $14 \mathrm{~d}$ of cold storage. Fruit from all treatments were considered immature after $28 \mathrm{~d}$ of cold storage, and the mangoes kept at (1\%, 5\% and $10 \%) \mathrm{O}_{2}$ maintained their initial firmness (119.9-125.6 N) when compared with those stored in higher oxygen atmospheres, which underwent a substantial loss of firmness (96.8-109.1 N). At low-oxygen levels, fruit also had lower contents of soluble pectin and total soluble sugars, whereas colour parameters were not affected by the atmospheres. After transfer from CA containers to ambient conditions, even from the lowest oxygen concentrations [(1\% and 5\%) $\mathrm{O}_{2}$ ], fruit ripened normally in just $8 \mathrm{~d}$ without presenting any low oxygen-related injury.

Brazil / Mangifera indica / fruits / controlled atmosphere storage / respiration / chemicophysical properties / quality / keeping quality

\section{Stockage des mangues 'Palmer' en atmosphères pauvres en oxygène.}

Résumé - Introduction. La conservation des mangues sous réfrigération traditionnelle n'est pas totalement efficace en raison de la sensibilité au froid de ce fruit, mais un stockage sous atmosphère contrôlée (AC) et à basse température peut améliorer son aptitude à la conservation et maintenir la qualité des fruits pendant cette période. De ce fait, notre étude a cherché à déterminer l'effet, sur des mangues 'Palmer' entreposées au froid $\left(12,8{ }^{\circ} \mathrm{C}\right)$, d'atmosphères contrôlées présentant diverses concentrations d'oxygène. Matériel et méthodes. Des fruits mûrs de mangues vertes ont été stockés en atmosphères contrôlées à (1\%, $5 \%, 10 \%, 15 \%$ et $21 \%)$ d'oxygène, $(12,8 \pm 0,6)^{\circ} \mathrm{C}$ et $\mathrm{HR} \sim 95 \%$ pendant 28 jours. Un lot de fruits a été stocké sans AC en chambre froide pour servir de lots témoins. Le mûrissement des fruits a été réalisé à température ambiante $\left[(25,2 \pm 0,6)^{\circ} \mathrm{C}\right.$, et $\left.\left.(92,8 \pm 2,4) \% \mathrm{HR}\right)\right]$ pendant des périodes de 14 jours. Résultats et discussion. Les fruits conservés en atmosphères avec des concentrations faibles en oxygène [(1\%, $5 \%$ et $10 \%) \mathrm{O}_{2}$ ] ont présenté les taux de production de $\mathrm{CO}_{2}$ significativement les plus bas après 14 jours d'entreposage au froid. Les fruits de tous les traitements ont été considérés comme immatures après 28 jours d'entreposage frigorifique, et les mangues maintenues à ( $1 \%$, $5 \%$ et $10 \%) \mathrm{O}_{2}$ ont conservé leur fermeté initiale [(119,9 à 125,6) N] par rapport à celles qui avaient été stockées sous atmosphères avec des concentrations d'oxygène plus élevées qui ont subi une perte substantielle de fermeté $[(96,8$ à 109,1) N]. Sous atmosphères à faibles concentrations en oxygène, les fruits ont présenté également les teneurs en pectines solubles et en sucres solubles totaux les plus faibles, tandis que les paramètres de couleur n'ont pas été affectés par l'atmosphère. Après transfert des conteneurs stockés sous AC à la température ambiante, même pour les plus faibles concentrations en oxygène [ $(1 \%$ et $5 \%) \mathrm{O}_{2}$ ], les fruits ont mûri normalement en seulement 8 jours sans présenter de blessures liées aux faibles teneurs en oxygène.

Brésil / Mangifera indica / fruits / stockage en atmosphère contrôlée / respiration / propriété physicochimique / qualité / aptitude à la conservation 


\section{Introduction}

Brazil is the world's seventh largest mango producer [1] and in general its commercial production is based on the cultivation of American varieties, such as 'Tommy Atkins', 'Haden', 'Kent', 'Keitt' and 'Palmer'. More recently, late season varieties have increased in importance and 'Palmer' has been the most preferable choice due to its quality characteristics and consumer preference.

At ambient temperature mango ripening occurs rapidly and fruit quality can be maintained for just $8 \mathrm{~d}$ [2]. Low temperatures can extend mango shelf-life to around $16 \mathrm{~d}$; however, mango conservation under traditional refrigeration systems is not totally efficient due to its susceptibility to chilling injury at temperatures lower than $13^{\circ} \mathrm{C}$ [3]. However, controlled atmosphere (CA) in association with low temperature can improve mango storability and maintain fruit quality during long-term storage [2, 4, 5]. Storage under CA has been used to extend the shelf-life of a wide range of mango varieties, e.g., 'Kensington Pride' [6], 'Kent' [7, 8], 'Tommy Atkins' [8, 9] and 'Haden' [10].

Kader recommended atmospheres containing 5\% oxygen $\left(\mathrm{O}_{2}\right)$ and 5\% carbon dioxide $\left(\mathrm{CO}_{2}\right)$ in order to extend mango shelf-life [11], although it is known that some varieties can tolerate higher $\mathrm{CO}_{2}$ levels and levels of $\mathrm{O}_{2}$ lower than $2 \%$ [8]. The recommendation of $5 \% \mathrm{O}_{2}$ and $5 \% \mathrm{CO}_{2}$ is commonly used during storage of mangoes under CA conditions. Lizada et al. reported that fruit of the 'Tommy Atkins' variety extended its shelf-life up to $31 \mathrm{~d}$ in CA containing $5 \% \mathrm{CO}_{2}$ and $5 \% \mathrm{O}_{2}$ [12]. However, these levels did not increase the shelf-life of 'Kent' mango, even when the $\mathrm{CO}_{2}$ level was raised to $10 \%$ [7]. On the other hand, Lizada and Ochagavia reported that CA with $10 \% \mathrm{CO}_{2}$ and $5 \% \mathrm{O}_{2}$ increased the shelf-life of fruit of this variety up to $29 \mathrm{~d}$, eight days more than the control [9].

Although promising, the responses of mango fruit to controlled atmosphere have been contradictory, as some varieties show just a tiny increase in shelf-life [13], whereas the shelf-life of other varieties can be extended more than one month [7].
Although it is possible to find studies regarding the use of CA during storage of mangoes, there is no recommendation for the 'Palmer' variety. The objective of our study was to determine the best oxygen concentration for the storage of 'Palmer' mango during cold storage and its effect on ripening.

\section{Materials and methods}

\subsection{Plant material}

Mature green mango fruits (Mangifera indica L. cv. 'Palmer') were obtained from a commercial orchard located in Taquaritinga, São Paulo State, Brazil. The maturity index was based on pulp colour (creamywhite $=$ immature and yellow $=$ mature) with fruit presenting titratable acidity $(\mathrm{TA})=$ $0.76 \mathrm{~g} \cdot 100 \mathrm{~g}^{-1}, \mathrm{pH}=3.55$, soluble solids content $(\mathrm{SSC})=7.2 \%,[\mathrm{SSC} / \mathrm{TA}]$ ratio $=9.90$, firmness $=127.50 \mathrm{~N}$, and purple-green peel $\left(L^{*}=38.16\right.$, Chroma $=9.31$ and Hue $=$ 346.90). After harvest, these fruits were transported to the laboratory within $1 \mathrm{~h}$.

\subsection{Controlled atmosphere treatments}

The 'Palmer' mango fruits were placed into hermetic plastic containers (20 L) under a continuous humidified gas flow system of $100 \mathrm{~mL} \cdot \mathrm{min}^{-1}$. The flow rate and gas mixtures were established using a mixing board with glass capillary tubes as flow regulators [14]. Compressed air was used as an oxygen $\left(\mathrm{O}_{2}\right)$ source and nitrogen $\left(\mathrm{N}_{2}\right)$ was obtained from cylinders (White Martins Gases Industriais Ltda., Sertãozinho, Brazil). Both gases were mixed in order to obtain the following oxygen levels: 1\%, 5\%, 10\%, 15\% and 21\% (container-stored control). Supply and exhaust gas composition were monitored every day using a Dansensor Checkmate 9001 atmosphere analyser (PBI Dansensor, Denmark). A single CA container containing 36 fruit represented an experimental unit and was replicated three times for each CA composition. Similarly, a plastic tray containing 36 fruit served as tray-stored control and was replicated three times (tray-stored control). The storage temperature was $(12.8 \pm 0.6)^{\circ} \mathrm{C}(\mathrm{RH} \sim 95 \%)$ and fruit ripening 
was carried out in ambient conditions $\left[(25.2 \pm 0.6){ }^{\circ} \mathrm{C},(92.8 \pm 2.4) \% \mathrm{RH}\right]$ at intervals of $14 \mathrm{~d}[(0,14$ and 28$) \mathrm{d}]$, in order to verify the effect of CA on ripening. The evaluations were performed immediately after the fruits were withdrawn from CA storage $[(0,14$ and 28) $d]$ and when the fruit was considered ripe $[(0+12),(14+8)$ and $(28+$ 8) d].

\subsection{Respiration rate}

Every two days during CA storage, thirty-six fruits of each oxygen concentration and the tray-stored control, three replicates, were sealed in $20-\mathrm{L}$ containers at $(12.8 \pm 0.6)^{\circ} \mathrm{C}$ for one hour. Similarly, every two days after transfer to ambient conditions, two fruits of each oxygen concentration, three replications, were sealed in 3.2-L containers at $(25.2 \pm 0.6)^{\circ} \mathrm{C}$ for one hour. Initially (0 hour) and after one hour, $0.3-\mathrm{mL}$ gas samples from the container headspaces were analysed for $\mathrm{CO}_{2}$ using a Finningan 9001 gas chromatograph (Finningan Corporation, San Jose, USA) equipped with a Porapack-N column and a thermal conductivity detector. Nitrogen, at a rate of $30 \mathrm{~mL} \cdot \mathrm{min}^{-1}$, was used as the carrier gas. Data were integrated using Borwin 1.20 software (JMBS Developpements, Le Fontanil, France).

\subsection{Weight loss}

The fruits of all treatments were initially weighed on a Marte AS 2000 balance with 0.01 g precision (Marte, São Paulo, Brazil) and the difference in weight was calculated and expressed as a percentage (\%).

\subsection{Visual appearance}

An untrained panel (10 members) evaluated the fruits based on a 1-5 scale, describing the overall fruit quality: 5 , excellent; 4 , very good; 3, regular; 2 , bad; and 1 , very bad.

\subsection{Firmness}

Pulp firmness was measured using an Effegi fruit tester (Bishop FT 327 Penetrometer, Alfonsine, Italy) with an 8.0-mm diameter tip. The peel from opposite sides was removed and two measurements per fruit were determined in the equatorial region [15].

\subsection{Colour}

Colour measurements $\left(L^{*}, a^{*}, b^{*}\right)$ were taken on three fruits of each oxygen concentration and tray-stored control. These values were transformed into chromaticity $\left(\mathrm{C}=\sqrt{a^{2}+b^{2}}\right)$ and hue angle (Hue $=\operatorname{tg}^{-1}\left(\frac{\mathrm{b}}{\mathrm{a}}\right)$ according to McGuire [16]. A Minolta CR-400 (Minolta Corp., Osaka, Japan) was used to measure external colour. The mean of two readings per fruit (equator reading) was determined.

\subsection{Chemical analysis}

Mangoes ( 4 fruits $\times 3$ replicates per treatment) without peels were homogenised in a blender and the homogenate was used to determine soluble solids content (SSC), titratable acidity (TA) and $\mathrm{pH}$ [17] (procedures 920.151, 932-12 and 945-27, respectively). The [SSC/TA] ratio was also calculated. The homogenates of all samples were frozen at $-20{ }^{\circ} \mathrm{C}$ and subsequently used for determining total soluble sugars [18], reducing sugars [19], and total and soluble pectin contents [20,21].

\subsection{Statistical analysis}

The experiment was laid out in a completely randomised factorial design with two factors: tray-stored control and the oxygen levels as the first factor and the storage duration $[(0,14$ and 28$) d]$ as the second factor. The data of the fruits of all treatments immediately removed from the CA conditions were subjected to analysis of variance, and the treatment means were compared using Tukey's test at a significance level of $P<0.05$. The data were analysed using the PROC MIXED procedure of the Statistical Analysis System [22]. Fruits transferred to ambient conditions were also statistically analysed according to a completely randomised design with five treatments (oxygen concentration) and three replicates of six fruits. 


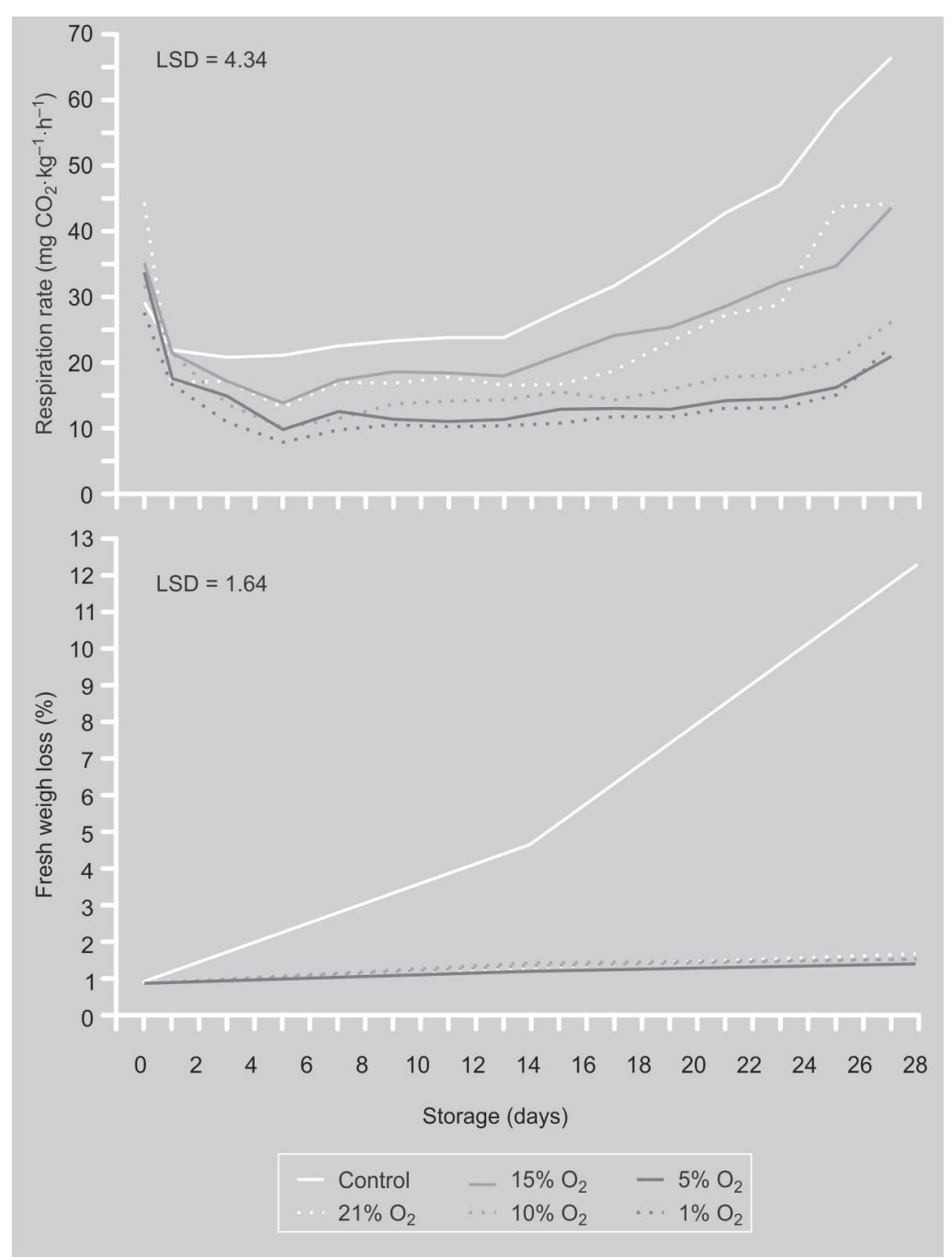

Figure 1.

Respiration rate and fresh weight loss of 'Palmer' mango fruit stored at $12.8^{\circ} \mathrm{C}$ under controlled atmosphere with different levels of oxygen for up to $28 \mathrm{~d}$.

\section{Results and discussion}

\subsection{Low-oxygen storage}

Storage under the controlled atmosphere (CA) with different levels of oxygen significantly affected the respiration rate of 'Palmer' mango fruit (figure 1). The fruits maintained in CA storage with $(1 \%, 5 \%$ and 10\%) $\mathrm{O}_{2}$ presented the lowest respiration rates throughout the cold storage period $(p<0.05)$. There was also a gradual increase in respiration as oxygen levels were raised to $(15 \%$ and $21 \%) \mathrm{O}_{2}$ and in the tray-stored control (figure 1). Beyond the third storage day, the tray-stored control fruits presented the highest respiration rates compared with the other CA treatments $(p<0.05)$.
The lowest respiration rates presented by the fruits stored in the atmospheres with low oxygen levels [(1\%, 5\% and 10\%) $\mathrm{O}_{2}$ ] can be related to its effect on key regulatory steps of glycolysis and, consequently, in respiration, by inhibiting the activity of phosphofructokinase and pyruvate kinase enzymes in the conversation of fructose-6-phosphate into fructose-1,6-bisphosphate and phosphoenol pyruvate into pyruvate, respectively [23].

The adequate use of CA can also contribute to reduced fruit sensitivity to ethylene, mainly at levels of oxygen below 8\% [24]. Atmospheres with low $\mathrm{O}_{2}$ concentrations can inhibit the biosynthesis of ethylene by blocking the ethylene linkage to the receptor responsible for triggering the autocatalytic biosynthesis of this hormone [25]. However, Bender and Brecht reported that the oxygen level had little influence on the ethylene biosynthesis in 'Kent' and 'Tommy Atkins' mangoes [8], possibly because the oxygen level $\left(3 \% \mathrm{O}_{2}\right)$ was still adequate in relation to the apparent $K_{m}$ of ACC oxidase $\left(0.4 \% \mathrm{O}_{2}\right)$ observed in mangoes by Kuai and Dilley [26].

During CA storage, 'Palmer' mango fruit, independently of the oxygen concentration, lost less weight than the fruits stored only in the cold room tray-stored control (figure 1). Controlled-atmosphere-stored fruits lost just $0.74 \%$ of their original weight, mainly due to the moisture control provided by the humidified gas flow, as the relative humidity in the CA containers was around $\sim 95 \%$ compared with the cold room [(68.9 \pm 5.9$) \%]$ tray-stored control. The difference in relative humidity, water loss, might have caused water stress and a consequent increase in the respiration rate and ethylene production of fruits from traystored control (figure 1), similar to results reported by Nakano et al. for 'Tonewase' persimmon [27].

Although tray-stored control fruits presented high weight loss values, according to the panellists the fruits were considered very good $(4.0 \pm 0.2)$ after $28 \mathrm{~d}$ of CA storage (figure 2). On the other hand, the fruits stored in CA received better scores as they were considered excellent throughout cold storage (figure 2), possibly due to the 
increase in relative humidity of the gas flow. Shriveling affected the appearance of the tray-stored control treatment just after transfer to ambient conditions (figure 2).

The CA storage with different levels of oxygen did not affect the colour parameters (table I). Fruit were initially considered immature with dark $\left(L^{*}=38.1 \pm 1.5\right)$, not very saturated (chromaticity $=9.3 \pm 3.4$ ) and purple peel (Hue angle $=346.9 \pm 7.8$ ) . The initial immaturity plus the effects of cold storage and its association with CA could have contributed to the absence of marked modifications in colour parameters (table I). 'Kensington Pride' mango fruit stored at $13{ }^{\circ} \mathrm{C}$ did not reach the maximum characteristic colour of this variety [28], similarly to mangoes of other varieties which presented reduced carotenoid development under cold storage [29, 30]. Therefore, atmosphere control with low $\mathrm{O}_{2}$ concentration did not affect colour modification of 'Palmer' mango fruit during cold storage; in this regard, the temperature should have played the major role.

The fruit stored under CA containing (1\%, $5 \%$ and $10 \%) \mathrm{O}_{2}$ remained firmer $(>120 \mathrm{~N})$ than those of the other oxygen levels and tray-stored control, mainly after $14 \mathrm{~d}$ of cold storage (figure 2). Tray-stored control fruits and those stored in CA with $(15 \%$ and $21 \%)_{2}$ (container-stored control) showed a sharp reduction in firmness, even though the pulp was considered very hard $(\sim 100 \mathrm{~N})$, according to Mitcham and McDonald [31] (figure 2). The absence of great modification in firmness of the fruits stored in CA with (1\%, 5\% and 10\%) oxygen can be related to the inhibition of the expression of many enzymes involved in the breakdown of starch molecules and pectic compounds [23, 32]. In 'Palmer' mangoes that remained firmer, stored in low oxygen, less starch mobilisation occurred, which was related to total soluble sugar (TSS) content, and reduced pectin solubilisation, which is responsible for cell wall integrity. Thus, the lowest TSS content presented in these fruits can be due to the reduced starch breakdown which led the fruits to remain firmer, as starch is responsible for mango pulp firmness [31]. Low levels of sugars (TSS) can also be related to lower respira-

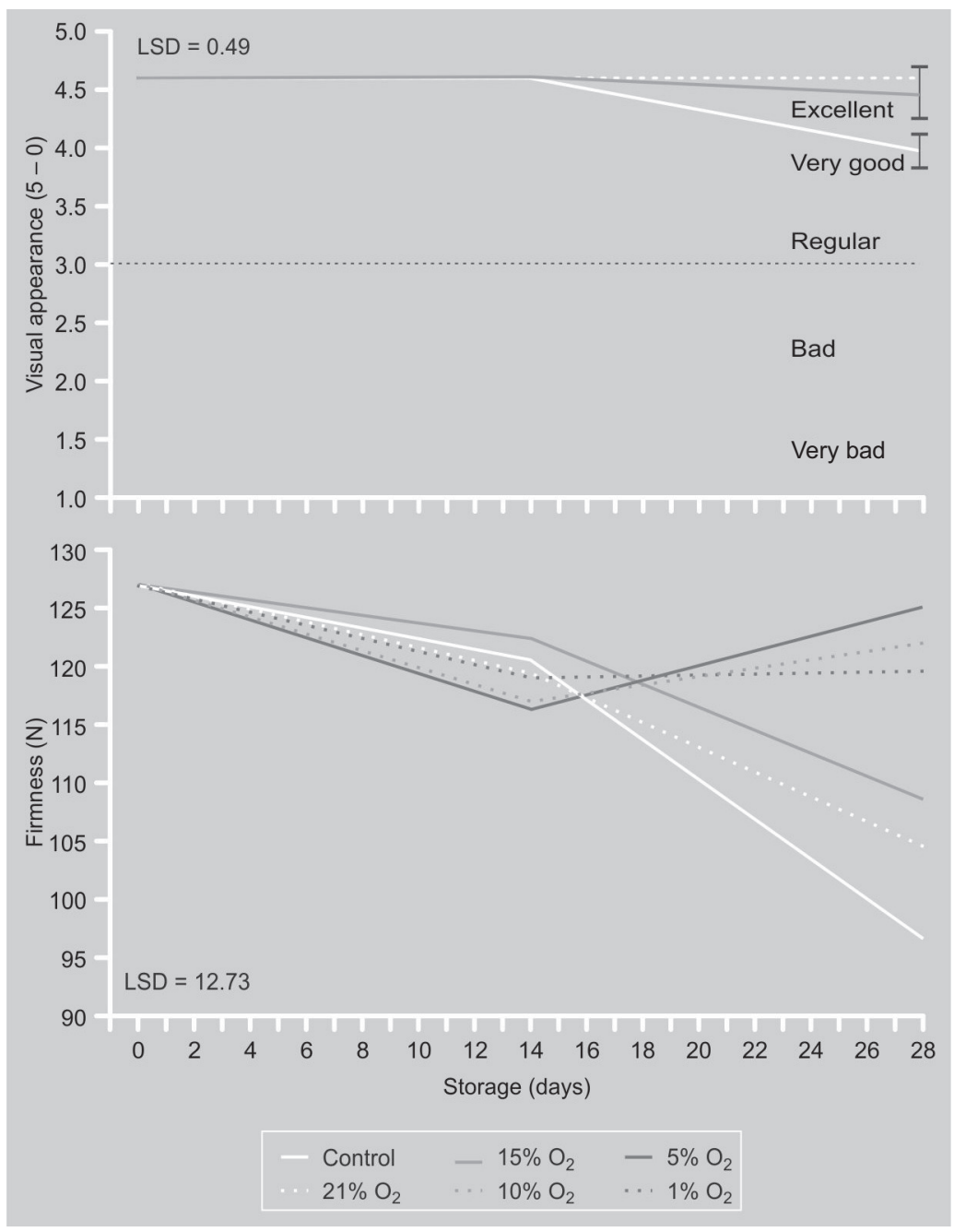

tory activity of these groups of fruits (fig- Figure 2.

ure 1), as a great part of the energy required Visual appearance (5 to 1) and by the fruit is supplied through aerobic res- firmness of 'Palmer' mango piration, which involves the breakdown of fruit stored at $12.8^{\circ} \mathrm{C}$ under several organic substances, starch among controlled atmosphere with them [32]. Therefore, at low $\mathrm{O}_{2}$ concentrations the breakdown of starch molecules different levels of oxygen for up to $28 \mathrm{~d}$. 


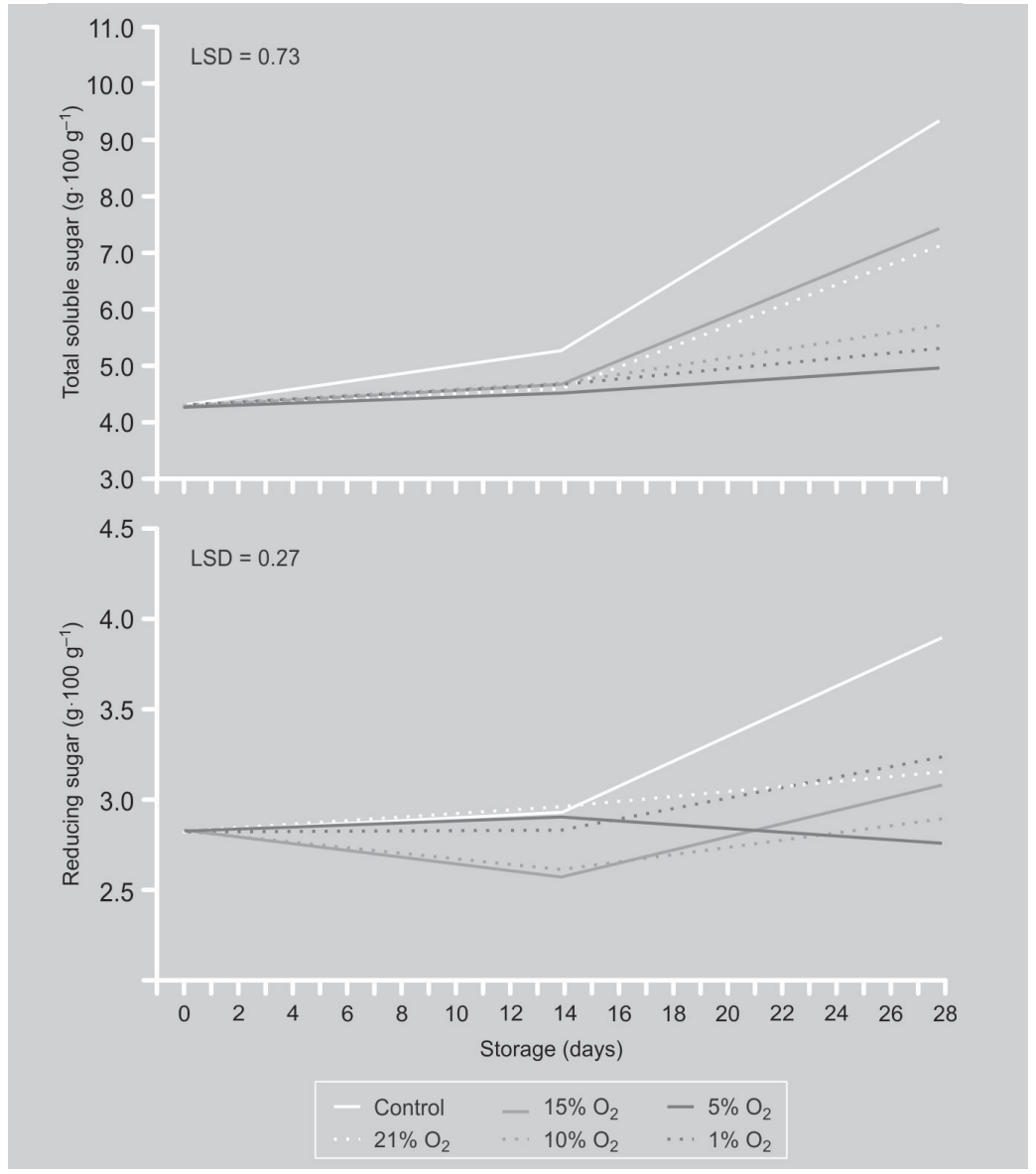

'Palmer' mango fruit stored in $(1 \%, 5 \%$ and $10 \%) \mathrm{O}_{2}$ also presented lower soluble pectin contents than the fruits of tray-stored control and the atmosphere containing (15\% and 21\%) $\mathrm{O}_{2}$ (container-stored control) (figure 4). Thus, the lower pectin solubilisation of these fruits indicates that the breakdown of cell wall compounds was inhibited, possibly due to a reduction of the activity of pectinolic enzymes, which could have led these fruits to remain firmer even after $28 \mathrm{~d}$ of cold storage (figure 4).

Generally, during mango ripening soluble solids content (SSC) increases due to starch breakdown [34]; however, as previously reported, fruits stored under CA with (1\%, 5\% and 10\%) $\mathrm{O}_{2}$ presented the lowest sugar contents (TSS), which probably reflected on the SSC (figure 4). During storage, tray-stored control fruits and those stored in the atmosphere containing higher oxygen concentrations $\left(15 \% \mathrm{O}_{2}\right.$ and $21 \% \mathrm{O}_{2}$-container-stored control) showed a sharp increase in SSC, mainly the tray-stored

\section{Figure 3.}

Total soluble sugar and reducing sugar contents of 'Palmer' mango fruit stored at $12.8^{\circ} \mathrm{C}$ under controlled atmosphere with different levels of oxygen for up to $28 \mathrm{~d}$.

\section{Table I.}

Effect of atmospheres on colour, pH, titratable acidity (TA), soluble solids contents (SSC) and [SSC / TA] ratio of 'Palmer' mango fruit after $28 \mathrm{~d}$ of storage at $12.8^{\circ} \mathrm{C}$.

\begin{tabular}{|c|c|c|c|c|c|c|}
\hline \multirow[t]{2}{*}{ Treatment } & \multicolumn{3}{|c|}{ Colour } & \multirow[t]{2}{*}{$\mathrm{pH}$} & \multirow{2}{*}{$\begin{array}{l}\text { Titratable acidity } \\
\quad\left(\mathrm{g} \cdot 100 \mathrm{~g}^{-1}\right)\end{array}$} & \multirow{2}{*}{$\begin{array}{c}{[\mathrm{SCC} / \mathrm{TA}]} \\
\text { ratio }\end{array}$} \\
\hline & Lightness & Chromaticity & Hue angle & & & \\
\hline \multicolumn{7}{|l|}{ Atmospheres (A) } \\
\hline Control & 36.75 & 11.67 & 249.82 & 3.58 & 0.84 & 11.43 \\
\hline $21 \% \mathrm{O}_{2}$ & 37.83 & 11.12 & 277.70 & 3.56 & 0.77 & 10.73 \\
\hline $15 \% \mathrm{O}_{2}$ & 37.80 & 10.75 & 275.03 & 3.57 & 0.81 & 10.53 \\
\hline $10 \% \mathrm{O}_{2}$ & 37.95 & 11.04 & 299.82 & 3.57 & 0.84 & 9.17 \\
\hline $5 \% \mathrm{O}_{2}$ & 36.72 & 10.61 & 275.03 & 3.61 & 0.83 & 9.33 \\
\hline $1 \% \mathrm{O}_{2}$ & 38.56 & 10.23 & 313.17 & 3.58 & 0.80 & 10.69 \\
\hline \multicolumn{7}{|l|}{ Storage (B) } \\
\hline $0 \mathrm{~d}$ & 38.19 & $9.31 \mathrm{c}$ & $240.90 \mathrm{~b}$ & $3.55 b$ & $0.76 \mathrm{~b}$ & $9.90 \mathrm{ab}$ \\
\hline $14 \mathrm{~d}$ & 36.87 & $12.42 \mathrm{a}$ & $299.45 \mathrm{a}$ & $3.60 \mathrm{a}$ & $0.79 \mathrm{~b}$ & $9.54 \mathrm{~b}$ \\
\hline $28 d$ & 37.75 & $10.99 \mathrm{~b}$ & 305.34 a & $3.58 \mathrm{ab}$ & $0.90 \mathrm{a}$ & $11.50 \mathrm{a}$ \\
\hline \multicolumn{7}{|l|}{ Interaction } \\
\hline$(A) \times(B)$ & NS & NS & NS & NS & NS & NS \\
\hline Standard deviation & 1.84 & 1.73 & 58.56 & 0.07 & 0.14 & 2.45 \\
\hline
\end{tabular}


control fruits, which presented the highest SSC after $28 \mathrm{~d}$ of cold storage (figure 4 ).

Titratable acidity (TA) did not vary between treatments $(p<0.05)$; however, it increased significantly during cold storage, affecting $\mathrm{pH}$ values (table $I$ ). Increases in titratable acidity are frequently reported during mango cold storage [28]. Therefore, during storage there was a delay in the ripening process with consequent retention of organic acids due to refrigeration, as the oxygen levels did not demonstrate any significant effect concerning TA (table I).

As the [SSC / TA] ratio is considered to be one of the most practical methods to indicate flavour, mainly when mangoes are destined for fresh consumption [24], the low ratios presented in this study at the end of CA storage are not appropriate for immediate fruit consumption (table I). Despite the fact of the significant delay in ripening of the fruit stored in CA with (1\%, 5\% and 10\%) $\mathrm{O}_{2}$; especially for reducing respiration rates, maintained firmness, total soluble sugars, reducing sugars and soluble pectin contents, these fruits were not appropriate for consumption at the moment of removal from CA, as they were immature. Fruit quality was quite similar to the fruit barely harvested at the beginning of the storage. For this reason, fruits were transferred to ambient conditions in order to ripen and verify the effect of CA on ripening.

\subsection{Ambient ripening}

During ripening in ambient conditions $\left(25.2^{\circ} \mathrm{C}, 92.8 \% \mathrm{RH}\right)$, the respiration rates of 'Palmer' mango fruits previously stored at different oxygen concentrations for $14 \mathrm{~d}$ increased even for those fruits stored at low $\mathrm{O}_{2}$ concentrations $[1 \%, 5 \%$ and $10 \%) \mathrm{O}_{2}$, but without presenting any significant difference among treatments (figure 5). In ambient conditions, fruit showed a steady increase in $\mathrm{CO}_{2}$ production rates without a climacteric peak (figure 5). On the other hand, after $28 \mathrm{~d}$ under CA storage, the oxygen concentrations did affect the respiratory activity of the fruit transferred to ambient conditions (figure 5). We observed that the fruit previously stored in atmospheres with low $\mathrm{O}_{2}$ concentrations (1\%, 5\% and 10\%)

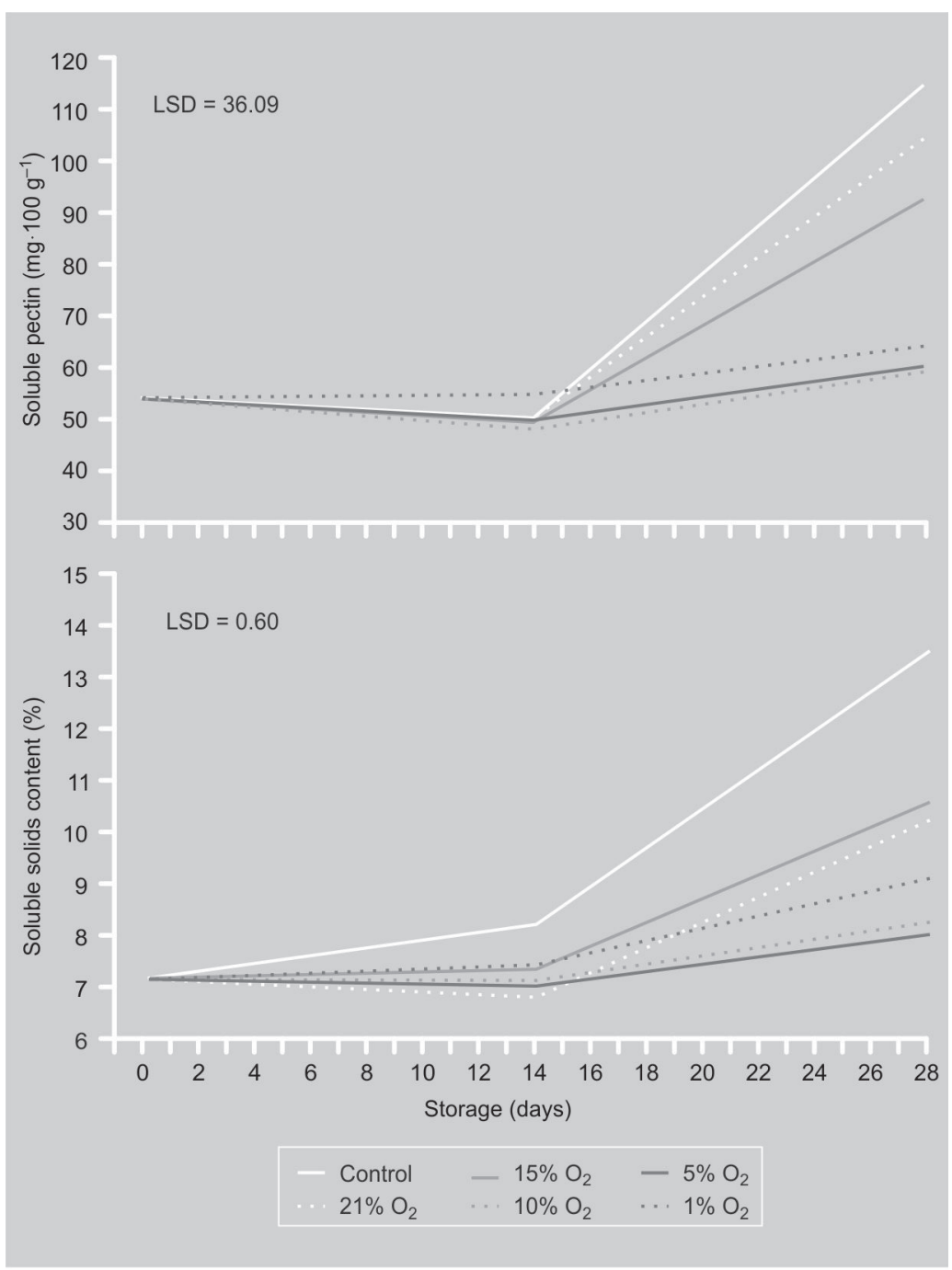

initially showed the lowest respiratory activities, which just levelled with the $21 \% \mathrm{O}_{2}$ (container-stored control) rates after $5 \mathrm{~d}$ in ambient conditions (figure 5). These differences can be related to the regulation of the metabolic pathways, which had led the mangoes previously stored at $(1 \%, 5 \%$ and $10 \%) \mathrm{O}_{2}$ to show reduced respiratory activities and, consequently, delaying ripening. Singh and Pal reported the same trend during guava ripening in ambient conditions after CA storage, and they related the suppression and delay of the climacteric rise to the residual effect of CA on respiration [35]. Despite these differences, the increase in $\mathrm{CO}_{2}$ production by 'Palmer' mango fruit after a short period in ambient
Figure 4.

Soluble pectin contents and soluble solids contents of 'Palmer' mango fruit stored at $12.8^{\circ} \mathrm{C}$ under controlled atmosphere with different levels of oxygen for up to $28 \mathrm{~d}$. 


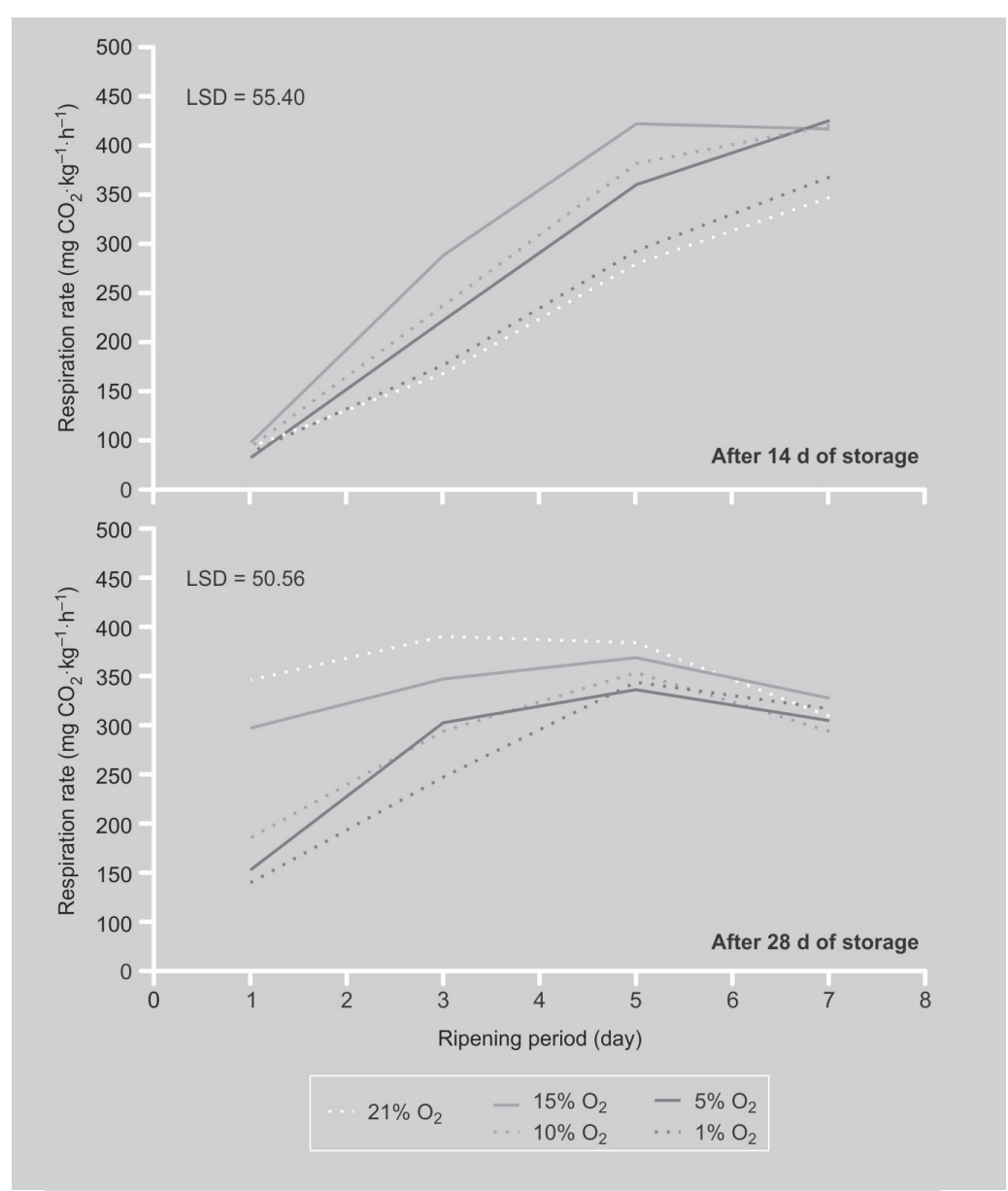

Figure 5.

Respiration rate of 'Palmer' mango fruit during ripening in ambient conditions $\left(25.2^{\circ} \mathrm{C}\right)$ after $14 \mathrm{~d}$ of storage and after $28 \mathrm{~d}$ of storage in controlled atmosphere at $12.8^{\circ} \mathrm{C}$. chondrial structure as a consequence of the prolonged exposition to low $\mathrm{O}_{2}$ concentrations, differently from what happened in extreme conditions $\left(50 \% \mathrm{CO}_{2}\right.$ and $75 \%$ 8-d post-storage holding period especially in these treatments, as observed for those kept in CA with (15\% and 21\%) $\mathrm{O}_{2}$ (traystored control fruit was destroyed during transfer to ambient conditions - missing data). The titratable acidity declined dramatically during ripening of mango fruit (table II). The data are consistent with what is normally observed during 'Palmer' mango ripening [36]. Therefore, 'Palmer' mango fruit can be stored in atmospheres containing between (1\% and 10\%) $\mathrm{O}_{2}$ without affecting its ripening process. It should be noted that these levels are quite similar to the $5 \% \mathrm{O}_{2}$ recommended for other American mango varieties.

\section{Conclusions}

The mango cultivar 'Palmer' may be stored at low temperature $\left(12.8^{\circ} \mathrm{C}, \sim 95 \% \mathrm{RH}\right)$ supplemented with atmospheres containing (1\% to $10 \%) \mathrm{O}_{2}$ for up to $28 \mathrm{~d}$. The most significant effects of controlled atmosphere in mango included reduction of the respiration rate, delayed ripening and maintenance of the fruit quality. Controlled atmosphere storage seems to be promising for shipping of 'Palmer' mango fruit by marine transport to distant markets, which may take three or four weeks. However, the CA requirements need to be evaluated for storing and transporting mangoes in other atmospheres and at temperatures other than $12.8^{\circ} \mathrm{C}$ because changing storage conditions may alter fruit quality. $\mathrm{CO}_{2}$ ) of atmospheric control [8]. Thus, 'Palmer' mango fruits can be stored in atmospheres containing between $(1 \%$ and $10 \%)_{2} \mathrm{O}_{2}$ without affecting their respiratory metabolism.

The fruits previously stored in atmospheres containing low $\mathrm{O}_{2}$ concentrations (1\%, 5\% and $10 \%$ ) for $28 \mathrm{~d}$ ripened normally after $8 \mathrm{~d}$ in ambient conditions (table II). Soluble solids content increased during the

\section{Acknowledgments}

The authors would like to thank FAPESP for sponsoring this research (Proc. 05/56159-1) and providing the postdoctoral scholarship (Proc. 05/56160-0) of the first author. We would also like to thank José Maria Sigrist for his special help during the setting up of the flowboard system and Ogata Citrus for providing the fruit for this experiment. 
Table II.

Effect of atmospheres on weight loss, initial and final colour, firmness, visual appearance, titratable acidity (TA), soluble solids content (SSC), [SSC / TA] ratio, and pH of 'Palmer' mango fruit after $28 \mathrm{~d}$ of storage at $12.8^{\circ} \mathrm{C}$ plus $8 \mathrm{~d}$ in ambient conditions $\left(25.2^{\circ} \mathrm{C}\right)$.

\begin{tabular}{|c|c|c|c|c|c|c|c|c|c|c|c|c|c|}
\hline \multirow[t]{2}{*}{ Atmosphere } & \multirow{2}{*}{$\begin{array}{c}\text { weight } \\
\text { loss } \\
(\%)\end{array}$} & \multicolumn{3}{|c|}{ Initial colour ${ }^{a}$} & \multicolumn{3}{|c|}{ Final colour } & \multirow{2}{*}{$\begin{array}{l}\text { Firmness } \\
(\mathrm{N})\end{array}$} & \multirow{2}{*}{$\begin{array}{c}\text { Appearance } \\
\text { (5 to } 1)\end{array}$} & \multirow{2}{*}{$\begin{array}{c}\text { TA } \\
\left(\mathrm{g} \cdot 100 \mathrm{~g}^{-1}\right)\end{array}$} & \multirow{2}{*}{$\begin{array}{l}\text { SSC } \\
(\%)\end{array}$} & \multirow{2}{*}{$\begin{array}{l}{[\mathrm{SSC} / \mathrm{TA}]} \\
\text { ratio }\end{array}$} & \multirow[t]{2}{*}{$\mathrm{pH}$} \\
\hline & & $L^{*}$ & Chroma & Hue & $L^{*}$ & Chroma & Hue & & & & & & \\
\hline Control $^{C}$ & - & - & - & - & - & - & - & - & - & - & - & - & - \\
\hline $21 \% \mathrm{O}_{2}$ & 7.31 & 37.73 & 10.12 & 240.75 & 39.29 & 13.44 & 66.71 & 4.63 & 4.0 & 0.15 & 14.2 & 94.60 & 4.87 \\
\hline $15 \% \mathrm{O}_{2}$ & 7.35 & 37.80 & 9.83 & 200.27 & 38.55 & 13.36 & 65.41 & 8.53 & 4.0 & 0.26 & 12.7 & 63.77 & 4.28 \\
\hline $10 \% \mathrm{O}_{2}$ & 8.51 & 37.39 & 10.22 & 236.00 & 38.03 & 14.00 & 97.79 & 5.67 & 4.0 & 0.18 & 14.2 & 81.69 & 4.55 \\
\hline $5 \% \quad \mathrm{O}_{2}$ & 7.77 & 38.22 & 11.49 & 311.04 & 37.40 & 14.64 & 129.31 & 6.55 & 4.0 & 018 & 13.0 & 74.46 & 4.45 \\
\hline $1 \% \quad \mathrm{O}_{2}$ & 7.03 & 39.12 & 10.19 & 209.84 & 38.11 & 14.56 & 100.28 & 6.30 & 4.0 & 0.24 & 13.6 & 60.28 & 4.25 \\
\hline$F$ value & 0.3582 & 0.1933 & 0.5872 & 0.1436 & 0.3953 & 0.9065 & 0.8447 & 0.7077 & 0.5121 & 0.4689 & 0.0983 & 0.2252 & 0.1848 \\
\hline LSD & 2.41 & 2.27 & 3.50 & 136.67 & 3.06 & 5.63 & 21.57 & 9.02 & 0.46 & 0.22 & 1.93 & 49.53 & 0.83 \\
\hline
\end{tabular}

\section{References}

[1] Anon., FAOSTAT, FAO Statistics, Food and Agriculture Organization of the United Nations, Roma, Italy, 2007.

[2] Kader A.A., Postharvest biology and technology: an overview, in: Kader A.A. (Ed.), Postharvest technology of horticultural crops, Univ. Calif.: Div. Agric. Nat. Resour. Publ., Davis, U.S.A., 2003.

[3] Miltra S.K., Baldwin E.A., Mango, in: Miltra S.K. (Ed.), Postharvest physiology and storage of tropical and subtropical fruit, $C A B$ Int., Wallingford, U.K., 1997.

[4] Do J.Y., Salunkhe D.K., Almacenamiento en atmosfera controlada, in: Pantastico Er.B. (Ed.), Fisiología de la posrecolección, manejo y utilización de frutas y hortalizas tropicales y subtropicales, Cia. Editor. Cont., México, México, 1979.

[5] Kader A.A., A summary of CA requirements and recommendations for fruits other than apples and pears, Acta Hortic. 600 (2003) 737-740.

[6] McLauchan R.L., Barker L.R., Controlled atmospheres for Kensington mango storage: classical atmospheres, Dev. Postharvest Handl. Technol. Trop. Tree Fruits (1992) 4144.
[7] Trinidad M., Bósquez E., Escalona H., Días de León F., Pérez Flores L., Kerbel C., Ponce de León L., Muñoz C., Pérez L., Controlled atmosphere $\left(5 \% \mathrm{CO}_{2}-5 \% \mathrm{O}_{2}\right.$ and $10 \% \mathrm{CO}_{2}-$ $5 \% \mathrm{O}_{2}$ ) do not significantly increase the shelf life of refrigerated Kent Mangoes, Acta Hortic. 455 (1997) 643-653.

[8] Bender R.J., Brecht J., Respiração e produção de etanol e de etileno em mangas armazenadas sob diferentes concentrações de dióxido de carbono e oxigênio, Pesqui. Agropecu. Bras. 35 (2001) 865-871.

[9] Lizada L.A., Ochagavia A., Controlled atmosphere storage of mango fruits (Mangifera indica L.) cvs. Tommy Atkins and Kent, Acta Hortic. 455 (1997) 732-737.

[10] Bender R.J., Brech, J.K., Sargent S.A., Mango tolerance to reduced oxygen levels in controlled atmosphere storage, J. Am. Soc. Hortic. Sci. 125 (2000) 707-713.

[11] Kader A.A., Biochemical and physiological basis for effects of controlled and modified atmospheres on fruits and vegetables, Food Chem. 40 (1986) 99-100.

[12] Lizada M.C.C., Biglete-Flor N.A., Garcia N.L., The response of the 'Carabao' mango to controlled atmosphere, in: Mencarelli F. and Tonutti O. (Eds.), Proc. V Int. Postharvest 
Symp., ISHS, Acta Hortic. 682 (2004) Verona, Italy, 2004, p. 5.

[13] O'Hare T.J., Prassad A., The effect of temperature and carbon dioxide on chilling symptoms in mango, Acta Hortic. 343 (1993) 244250.

[14] Claypool L.L., Keefer R.M., A colorimetric method for $\mathrm{CO}_{2}$ determination in respiration studies, Proc. Am. Soc. Hortic. Sci. 40 (1942) 177-176.

[15] Watkins C., Harman J., Use of penetrometer to measure flesh firmness of fruit, Orchard. N.Z. 54 (1981) 14-16.

[16] McGuire R.G., Reporting of objective color measurements, HortScience 27 (1992) 254255.

[17] Anon., Official methods of analysis, AOAC, Patrícia Cuniff, Arlingt., U.S.A., 1997.

[18] Yemn E.W., Willis A.J., The estimation of carbohydrate in plant extracts by anthrone, Biochem. J. 57 (1954) 508-514.

[19] Miller G.L., Use of dinitrosalicylic acid reagent for determination of reducing sugars, Anal. Chem. 31 (1959) 426-428.

[20] McCready P.M., McComb E.A., Extraction and determination of total pectin materials, Anal. Chem. 24 (1952) 1586-1588.

[21] Bitter T., Muir H.M., A modified uronic acid carbazole reaction, Anal. Biochem. 34 (1962) 330-334.

[22] Anon., SAS User's guide: statistics, SAS Institute Inc., Cary, U.S.A., 1996.

[23] Tucker G.A., Introduction, in: Seymour G.B., Taylor J.E., Tucker G.A. (Eds.), Biochemistry of fruit ripening, Chapman \& Hall, London, U.K., 1993.

[24] Chitarra M.I.F., Chitarra A.B., Pós-colheita de frutos e hortaliças: fisiologia e manuseio, Editor. UFLA, Lavras, Brazil, 2005.

[25] Burg S.P., Burg E.A., Molecular requirements for the biological activity of ethylene, Plant Physiol. 42 (1967) 144-152.

[26] Kua, J., Dilley D.R., Extraction, partial purification and characterization of 1-aminocyclopropane-1-carboxylic acid oxidase from apple fruit, Postharvest Biol. Technol. 1 (1992) 203-211.

[27] Nakano R., Inoue S., Kubo Y., Inaba A., Water stress-induced ethylene in the calyx triggers autocatalytic ethylene production and fruit softening in 'Tonewase' persimmon grown in a heated plastic-house, Postharvest Biol. Technol. 25 (2002) 293-300.

[28] O'Hare T.J., Effect of ripening temperature on quality and composition changes of mango (Mangifera indica L.) cv. Kensington, Aust. J. Exp. Agric. 35 (1995) 259-263.

[29] Thompson A.K., The storage of mango fruits, Trop. Agric. 48 (1971) 63-70.

[30] Medlicott A.P., Reynolds S.P., Thompson A.K., Effects of temperature on the ripening of mango fruit (Mangifera indica L. var. Tommy Atkins), J. Sci. Food Agric. 37 (1986) 469-474.

[31] Mitcham E.J., McDonald R.E., Cell wall modification during ripening of 'Keitt' and 'Tommy Atkins' mango fruit, J. Am. Soc. Hortic. Sci. 117 (1991) 919-924.

[32] Wills R., McGlasson B., Graham D., Joyce D., Postharvest: an introduction to the physiology and handling of fruit, vegetables and ornamentals, UNSW Press, Sydney, Aust., 1998.

[33] Nakasone H.K., Paull R.E., Tropical fruits, CAB Int., Wallingford, U.K., 1998.

[34] Khader S.E.S.A., Effect of gibberellic acid and vapor guard on ripening amylase and peroxidase activities and quality of mango fruits during storage, J. Hortic. Sci. 67 (1992) 855-860.

[35] Singh S.P., Pal R.K., Controlled atmosphere storage of guava (Psidium guajava L.) fruit, Postharvest Biol. Technol. 47 (2008) 296306.

[36] Jenonimo E.M., Kanesiro M.A.B., Efeito da associação de armazenamento sob refrigeração e atmosfera modificada na qualidade de mangas 'Palmer', Rev. Bras. Frutic. 22 (2000) 237-243. 


\section{Almacenamiento de los mangos 'Palmer' en atmósferas pobres en oxígeno.}

Resumen - Introducción. La conservación de los mangos en refrigeración tradicional no es del todo eficaz, dado a la sensibilidad al frío de dicho fruto. Sin embargo, un almacenamiento en atmósfera controlada (AC) y a baja temperatura puede mejorar su aptitud de conservación y mantener la calidad de los frutos durante este periodo. Por ello, nuestro estudio quiso determinar el efecto que tienen ciertas atmósferas controladas de diversas concentraciones de oxígeno en los mangos 'Palmer' almacenados en frío $\left(12,8{ }^{\circ} \mathrm{C}\right)$. Material y métodos. Se almacenaron frutos maduros de mangos verdes en atmósferas controladas a (1\%, $5 \%, 10 \%, 15 \%$ y $21 \%$ ) de oxígeno, $(12,8 \pm 0,6)^{\circ} \mathrm{C}$ y HR $~ 95 \%$ durante 28 días. Un lote de frutos se almacenó sin AC, en cámara fría, como lote testigo. La maduración de los frutos se realizó a temperatura ambiente $\left[(25,2 \pm 0,6)^{\circ} \mathrm{C}\right.$, y $\left.\left.(92,8 \pm 2,4) \% \mathrm{HR}\right)\right]$ durante periodos de 14 días. Resultados y discusión. Los frutos conservados en atmósferas de flojas concentraciones de oxígeno $\left[(1 \%, 5 \%\right.$ y $\left.10 \%) \mathrm{O}_{2}\right]$ presentaron las tasas de producción de $\mathrm{CO}_{2}$ considerablemente más bajas, tras 14 días de almacenamiento en frío. Los frutos de todos los tratamientos se consideraron inmaduros, tras 28 días de almacenamiento frigorífico. Los mangos mantenidos a $(1 \%, 5 \%$ y $10 \%) \mathrm{O}_{2}$ conservaron su firmeza inicial [(119,9 a 125,6) N], en relación con los que se almacenaron en atmósfera de concentraciones de oxígeno más elevadas, los cuales, a su vez, padecieron una pérdida sustancial de firmeza [(96,8 à 109,1$)$ N]. En atmósferas de floja concentración de oxígeno, los frutos presentaron también los contenidos más bajos de pectinas solubles y de azúcares solubles totales, mientras que los parámetros de color no se vieron afectados por la atmósfera. Después de transferir a temperatura ambiente los contenedores almacenados en AC, incluso en las concentraciones más flojas de oxígeno [(1\% y $5 \%) \mathrm{O}_{2}$ ], los frutos maduraron normalmente en sólo 8 días, sin presentar ningún daño relacionado a los flojos contenidos de oxígeno.

Brasil / Mangifera indica / frutas / almacenamiento atmósfera controlada / respiración / propiedades fisicoquímicas / calidad / aptitud para la conservación 